\title{
Potential Assessment of Rumex spp. as a Source of Bioactive Compounds and Biological Activity
}

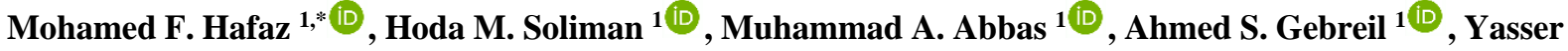 \\ A. El-Amier 1,* (D) \\ 1 Botany Department, Faculty of Science, Mansoura University, Mansoura, 35516, Egypt \\ * Correspondence: mfahafez@gmail.com (M.F.); yasran@mans.edu.eg (Y.E.);
}

Scopus Author ID 55791223000

Received: 7.04.2021; Revised: 15.05.2021; Accepted: 17.05.2021; Published: 10.06.2021

\begin{abstract}
Secondary metabolites from the shoots and roots of three Rumex species collected from three different habitats were investigated (Rumex dentatus collected from cultivated land, $R$. pictus collected from the coastal desert and $R$. vesicarius collected from the inland desert) and tested for antioxidant activity as well as for anti-microbial activity against some human pathogenic bacteria. The present study indicated that the quantitative analysis of shoot and root extracts of three Rumex spp. were found to be rich in tannins and phenolics composition. The aerial parts of the three plants exhibited the highest significant values compared to the root parts. The $\mathrm{MeOH}$ extracts of Rumex species showed adequate antioxidant activity, wherein the $\mathrm{IC}_{50}$ values of the $\mathrm{MeOH}$ from the cultivated sample was 41.61 and $31.31 \mathrm{mg} \mathrm{mL}^{-1}$, coastal samples were 34.99 and $23.99 \mathrm{mg} \mathrm{mL}^{-1}$, while the sample of inland showed $\mathrm{IC}_{50}$ value of 41.59 and $31.67 \mathrm{mg} \mathrm{mL}^{-1}$, for root and shoot, respectively. Furthermore, using a filter paper disc assay, the $\mathrm{MeOH}$ extracts of the three Rumex species showed a substantial anti-microbial inhibitory effect on the growth of 10 pathogenic bacteria. According to sensitivity, the tested organisms could be sequenced as following: E. coli $<$ K. pneumoniae $<$. typhi $<P$. aeruginosa for Gram-negative bacteria and B. subtilis $<$ S. pneumoniae $<$ L. monocytoyenes $<$ S. epidermis $<S$. aureus $<$ B. cereus for Grampositive bacteria. In addition, the antibacterial performance of $R$. dentatus root and $R$. vesicarius shoot $\mathrm{MeOH}$ extract is $100 \%$ broad spectrum against Gram-negative bacteria. A shoot of $R$. dentatus and $R$. pictus $\mathrm{MeOH}$ extract against Gram-positive bacteria is $83.3 \%$ broad spectrum. A further study is recommended for more characterization of the major compounds and assesses their efficiency and biosafety.
\end{abstract}

Keywords: Rumex spp.; xerophytes; antibacterial; antioxidant; phytochemical.

(C) 2021 by the authors. This article is an open-access article distributed under the terms and conditions of the Creative Commons Attribution (CC BY) license (https://creativecommons.org/licenses/by/4.0/).

\section{Introduction}

Medicinal plants are a major source of complex and highly structurally diverse chemical compounds (phytochemicals). In fact, plants represent an enormous reservoir of new, undiscovered and bioactive molecules, moreover, they represent an inexhaustible source of life-saving biological resources for the majority of the world's population $[1,2]$. Natural products sometimes have a pharmacological activity that can benefit treating diseases [3]. The demand for arable land, water, energy, and biological resources to provide a sufficient supply of food while protecting the quality of our environment is increasing as the world population continues to increase geometrically. As the world population expands, the food problem will become increasingly severe conceivably, with the number of malnourished reaching 3 billion [4]. 
Polygonaceae (knotweed family) is a family of flowering plants, most of the members are perennial herbaceous plants with swollen nodes, but trees, shrubs and vines are also present [5]. Meickle [6] reported that Polygonaceae comprises about 40 genera widely distributed, but chiefly in temperate regions of the northern hemisphere. Genus Rumex is considered one of the most important genera in this family, comprises about 150 species of annual, biennial and perennial herbs with a cosmopolitan distribution in temperate regions [7,8]. Rumex species has a long history of being used as a domestic herb. It's a gentle and safe laxative with a weaker action than rhubarb, so it's especially good for treating mild constipation. The plant has valuable cleansing properties and is useful for treating a wide range of skin problems. All parts of the plant can be used, though the root is most active medicinally $[9,10]$.

Rumex dentatus L. (dentate dock) is an annual, glabrous herb producing a slender, erect stem up to 70 or 80 centimeters in maximum height. It is widely distributed in Europe, Asia and the Mediterranean region, including Egypt [8]. It occurs in waste places, shores, canal banks and cultivated fields. It has been used as a leafy vegetable in the Mediterranean diet $[11,12]$. Rumex pictus Forssk. (veined dock) is also an annual, glabrous herb, 10-30 cm, stems decumbent and richly branched at the base. It is widely distributed in Syria, Arabia and the Mediterranean coast of Egypt [8]. Rumex vesicarius L. (bladder dock) is an annual semisucculent herb, pale green, $15-30 \mathrm{~cm}$ high. The plant is widely cultivated as a green leafy vegetable and medicinal properties in many parts of the world $[8,13]$. In Egypt, three plant species are growing wild and collected in spring and eaten fresh or cooked [14].

Rumex spp. is widely used as food, as a medicinal herb [15]. Previous chemical investigations have shown the presence of polyphenols, flavonoids, carotenoids, anthraquinones, tocopherols and ascorbic acid in different organs extract from Rumex spp. [1619]. Little information has been reported on the chemical composition and biological activity of $R$. pictus. However, Rumex spp. are reported to have various biological activities, as antioxidant, antibacterial, hepatoprotective, antiemetic, cytotoxic and phytotoxic [20-23].

As a result, plant communities in arid regions have a long history of using sustainable renewable resources for uncultivated areas in order to increase food production, animal feed, and the manufacturing of local raw materials [24,25]. This study was carried out to (i) assess the in vitro anti-microbial and antioxidant activities of three wild-grown Rumex sp. (Rumex dentatus, $R$. pictus and $R$. vesicarius) collected from three heterogeneous habitats, (ii) qualitative and quantitative investigation of some chemical constituents of the three samples, and (iii) evaluate the allelopathic activity of the three species against the nuisance weed, Chenopodium murale.

\section{Materials and Methods}

\subsection{Plant materials and extraction.}

Composite samples of the three Rumex species during the flowering stage from three different habitats were collected in plastic bags; the first location was cultivated land habitat with clay soil near Mansoura City, Nile delta, Egypt (31 $\left.04^{\prime} 46.76^{\prime \prime} \mathrm{N} 31^{\circ} 21^{\prime} 57.37^{\prime \prime} \mathrm{E}\right)$, sandy habitat near Gamasa City was the second location, northern Mediterranean coast, Egypt $\left(31^{\circ} 26^{\prime} 58.78^{\prime \prime} \mathrm{N} 31^{\circ} 28^{\prime} 36.14^{\prime \prime} \mathrm{E}\right)$.

While the third location was the inland wadi habitat with sandy and gravel soil north Eastern Desert (Wadi Araba), Egypt (2859'57.75"N 326'57.95"E). The collected plants were identified according to Boulos [8] by Dr. Yasser A. El-Amier Lecture of Plant Ecology, Botany 
Department, Mansoura University, Egypt. The plant materials were separated into root and shoot system, washed and dried at room temperature, reduced into small pieces before ground and packed in paper bags. The three samples of Rumex spp. were dried on air, then about 100 g powder of them were extracted in $70 \%$ hydro-methanol at room temperature $\left(27^{\circ} \mathrm{C} \pm 2\right)$. The extraction was filtered, and evaporated under a vacuum at $55^{\circ} \mathrm{C}$, then dried to give dark gum.

\subsection{Phytochemical analysis.}

\subsubsection{Qualitative phytochemical screening.}

Rumex spp. (Rumex dentatus, $R$. pictus, and $R$. vesicarius) air-dried shoot and root powder were subjected to preliminary phytochemical screening for alkaloids, saponins, tannins, phenolics, anthraquinone, steroid, flavonoids, glucosides, coumarins, and terpenoids using the standard methods mentioned by Harborne [26], Trease and Evans [27] and Sofowora [28].

\subsubsection{Quantitative estimation of some secondary compounds.}

Total phenolics, tannins, alkaloids, flavonoids and saponins of Rumex spp. (Rumex dentatus, $R$. pictus and $R$. vesicarius) samples were quantitatively estimated spectrophotometrically [29-32].

\subsection{Evaluation of antioxidant activity.}

In terms of radical scavenging activity, the antioxidants activity of the samples was measured using stable radical DPPH [33]. A methanol solution of $1 \mathrm{~mL}$ of each Rumex sample was prepared, mixed well and incubated at room temperature $\left(25^{\circ} \mathrm{C}\right)$ for $15 \mathrm{~min}$ in dark conditions at different concentrations $(5,10,20,30,40$ and $50 \mathrm{ppm})$, with the same volume of the methanol solution of $0.3 \mathrm{mM}$ DPPH. As standard, catechol was used. Use of UV visible spectrophotometer to determine the absorption decrease of $517 \mathrm{~nm}$ (Spectronic $21 \mathrm{D}$ model). The $\mathrm{IC}_{50}$ (the concentration of specimen required to reduce the absorbance of DPPH by 50\%) was calculated graphically. The percentage inhibition of the DPPH radical was calculated as follows:

$$
\% \text { Radical scavenging activity }=\left(1-\frac{\text { Absorbance of sample }}{\text { Absorbance of control }} \times 100\right.
$$

\subsection{Evaluation of antibacterial efficacy.}

\subsubsection{Bacterial strains.}

From the Laboratory of Bacteriology, Department of Botany, Faculty of Science, Mansoura University, Egypt, five Gram-negative bacteria: Pseudomonas aeruginosa (ATCC9027), Salmonella typhi (ATCC25566), Listeria monocytoyenes (ATCC19116), Escherichia coli (ATCC10536), and Klebsiella pneumoniae (ATCC10031), and four Grampositive bacteria; Bacillus subtilis (DMS1088), Entrobacter cloeoae (DMS30054), Streptococcus epidermis (EMCC1353t), and Staphylococcus aureus (ATCC6538) were taken. 


\subsubsection{Estimation of anti-microbial activity (Agar diffusion method)}

The agar diffusion assay was applied according to the method described by Cappuccino and Sherman [34]. The sterilized Whatman no.1 filter paper discs (6 $\mathrm{mm}$ in diameter) were impregnated with $100 \mu \mathrm{l}$ of the extract $(100 \mu \mathrm{g} / \mathrm{ml})$ and were then applied on the surface of agar plates freshly seeded with standard inoculate of young cultures. All Petri dishes were incubated at $37{ }^{\circ} \mathrm{C}$ for 24 hours. Experiments were done in triplicate; the diameter of the inhibition zone $(\mathrm{mm})$ was estimated and compared with DMSO as control. Standard antibiotics of chloramphenicol, penicillin and clotrimazole were used.

\section{Results and Discussion}

\subsection{Phytochemical constituents.}

The data of preliminary qualitative phytochemical screening of three Rumex spp. revealed that different species of Rumex plant are a good source of bioactive compounds due to their content of various phytochemicals. The powder of Rumex spp. shoot and root parts were subjected to phytochemical screening and the results were recorded in Table 1. In this study, the use of methanolic solvent showed different responses for the presence of phytoconstituents and according to the intensity of color or precipitates produced, the terms of scores are using as,,,-++++++ . The methanolic extract showed the presence of all the tested chemical constituents in the plant parts (shoot and root). However, steroids, glycosides and coumarins were absent in $R$. vesicarius root extract, anthraquinones and coumarins in the root extract of Rumex dentatus and R. pictus (Table 1). Plants are an abundant natural source of structurally diverse organic compounds that are not directly involved in normal growth, development, or reproduction but are thought to be required to adapt to their environment $[35,36]$.

On the other hand, comparative study of wild Rumex spp. shoot and root extracts revealed that they were high in tannins and phenolics composition. However, the aerial parts of the three samples exhibited the highest significant values compared to root parts. The present results showed that the contents of total phenolics, tannins, total flavonoids, alkaloids and saponins were in the range of 16.71-4.15, 10.39-3.44, 6.67-2.25, 7.87-2.15 and 5.24-2.69 mg/g DW, respectively (Figure 1).

Table 1. Qualitative phytochemical analysis of extracts of Rumex spp.

\begin{tabular}{|c|c|c|c|c|c|c|}
\hline \multirow{3}{*}{ Screening test } & \multicolumn{6}{|c|}{ Rumex spp. } \\
\hline & \multicolumn{2}{|c|}{ R. dentatus } & \multicolumn{2}{|c|}{ R. pictus } & \multicolumn{2}{|c|}{ R. vesicarius } \\
\hline & Shoot & Root & Shoot & Root & Shoot & Root \\
\hline Alkaloids & ++ & + & + & + & + & + \\
\hline Flavonoids & ++ & ++ & ++ & + & ++ & + \\
\hline Phenols & +++ & ++ & +++ & ++ & +++ & ++ \\
\hline Saponins & + & + & + & + & + & + \\
\hline Tannins & ++ & + & + & + & ++ & + \\
\hline Steroids & + & + & + & + & + & - \\
\hline Glycosides & ++ & + & + & + & + & - \\
\hline Anthraquinones & + & - & + & - & + & ++ \\
\hline Terpenes & + & + & + & + & + & + \\
\hline Coumarins & + & - & + & - & + & - \\
\hline
\end{tabular}

Positive mark $(+)$ indicates the presence of the phytochemical. Negative mark $(-)$ indicates the absence of the phytochemical.

According to phytoconstituent data, the concentration of bioactive compounds in shoot and root of Rumex spp. followed the order phenolics $>$ tannins $>$ flavonoid $>$ alkaloid $>$ 
saponins. Regarding the plant species, the concentrations of bioactive compounds were in $R$. vesicarius $>R$. pictus $>$ Rumex dentatus. Moreover, different plant species had variable mineral concentrations. These results are in good accordance with previous studies, which showed that high phenolic content in xero-halophytes as they mainly protect plant cells from drought and salinity [37]. Our results were similar to those reported by Beddou et al. [38] on R. pictus and $R$. vesicarius and Shakir et al. [39] on $R$. dentatus and $R$. hastatus. Whereas Ammar et al. [40] reported that alkaloids, saponins and coumarins were all absent from $R$. pictus and $R$. vesicarius.

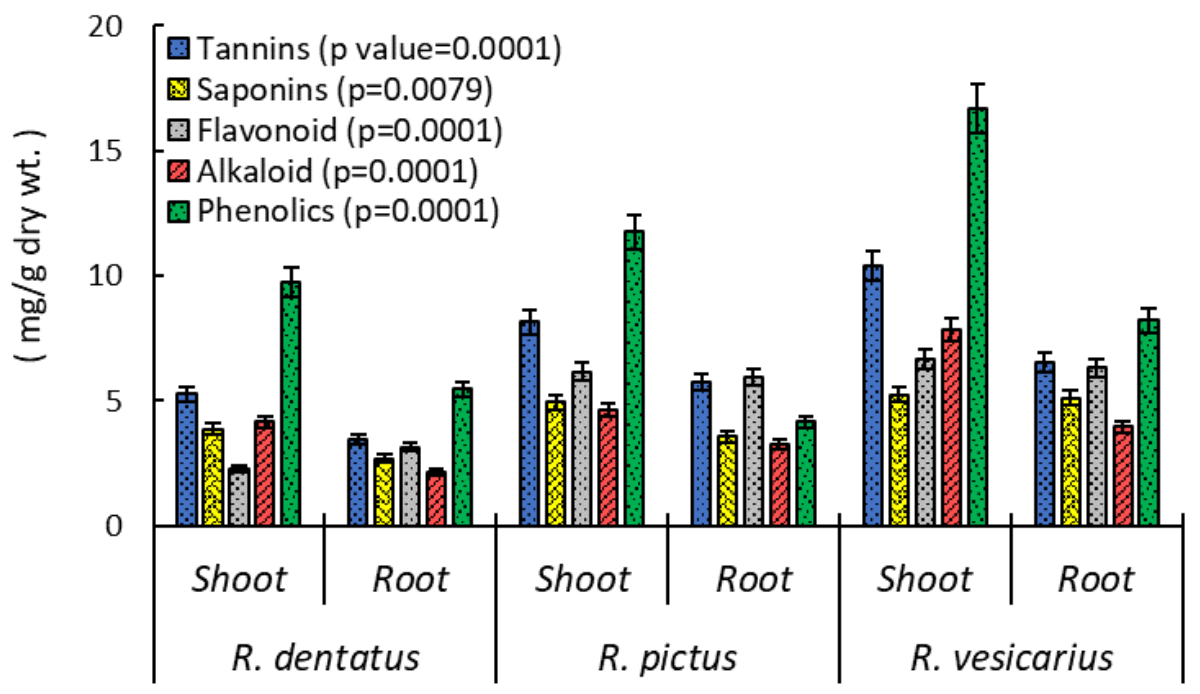

Figure 1. The concentration of the active constituents in $\mathrm{mg} / \mathrm{g}$ dry weight for the Rumex spp.

\subsection{Antioxidant activity of $\mathrm{MeOH}$ extract of Rumex species}

The $\mathrm{MeOH}$ extract of three Rumex spp. showed a significant reduction in the DPPH color in a concentration-dependent manner with respect to control (Figure 2). At $50 \mathrm{mg} \mathrm{mL}^{-1}$, the extracts of Rumex dentatus, $R$. pictus and $R$. vesicarius showed scavenging activities of $52.88 \%, 59.57 \%$ and $55.42 \%$, for root and $62.78 \%, 72.96 \%$ and $64.66 \%$ for a shoot, respectively. However, the lowest concentration $(5 \mathrm{mg} / \mathrm{ml})$ shows the lowest antioxidant activity (Figure 2). The $\mathrm{IC}_{50}$ values of the $\mathrm{MeOH}$ from the cultivated sample were 41.61 and $31.31 \mathrm{mg} \mathrm{mL}^{-1}$ for root and shoot, coastal samples were 34.99 and $23.99 \mathrm{mg} \mathrm{mL}^{-1}$. The IC50 values for the inland and coastal samples were 41.59 and $31.67 \mathrm{mg} \mathrm{mL}^{-1}$, respectively. Based on the $\mathrm{IC}_{50}$ values, ascorbic acid (a normal antioxidant) showed a 4-fold increase in antioxidant activity compared to the $\mathrm{MeOH}$ extract of the root sample and a 3-fold increase in antioxidant activity compared to the shoot sample of Rumex spp. in three different habitats. The $\mathrm{IC}_{50}$ is inversely proportional to the antioxidant power, where the lower the $\mathrm{IC}_{50}$, the higher the antioxidant activity (Figure 3).

The powerful antioxidant activity of Rumex $\mathrm{MeOH}$ extract can be attributed mainly due to secondary compounds [41]. The predominance of polyphenols may be the primary reason for the considerable observed antioxidant activity of Rumex spp. MeOH extract. Flavonoids, tannins and phenolic compounds have been found to be antioxidants in different plants, such as Diplotaxis harra [42], Fagonia species [43], Rubus fruits [44] and Aizoon canariense [45].

Moreover, the high content of phenolic compounds, flavonoids and tannins can be attributed to the antioxidant activity of the coastal and inland samples (Figure 1). Drought and salinity have been reported to be one of the key environmental factors, as both stresses can 
lead to several morphological, physiological, biochemical and metabolic changes as a mechanism for acclimation to stressful conditions [46]. In general, this difference between activities of the three Rumex spp. could be confirmed with the environmental and habitat conditions $[47,48]$.
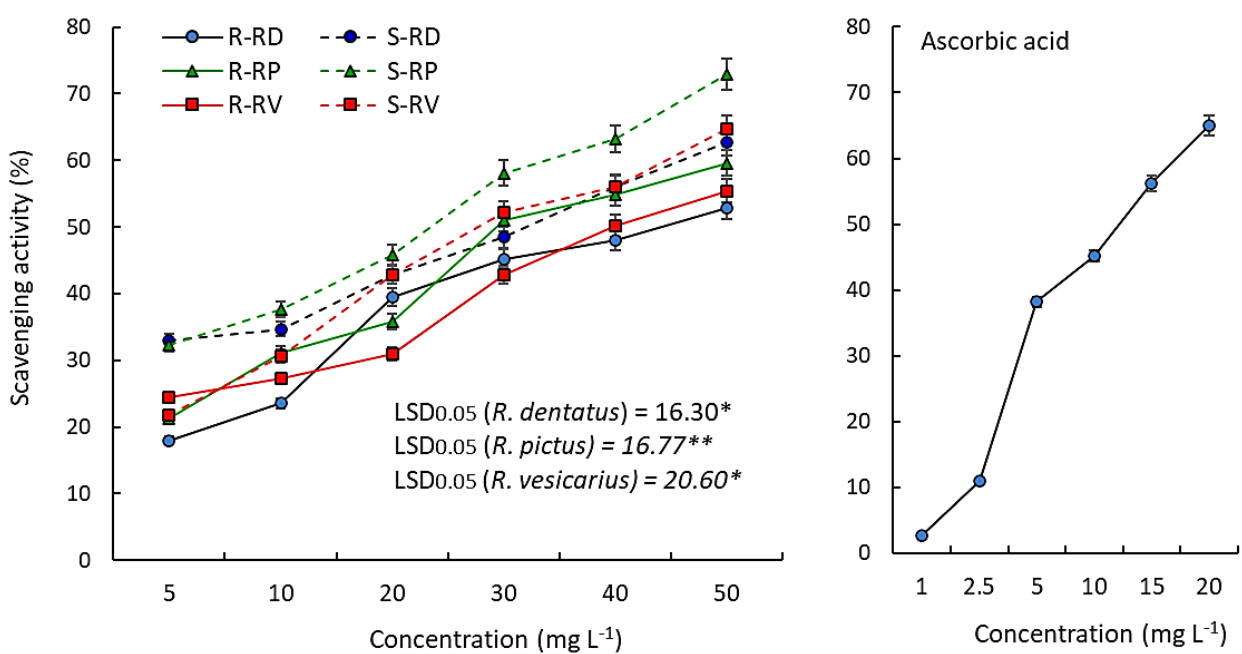

Figure 2. Scavenging activity percentage of 2,2-Diphenyl-1-picrylhydrazyl (DPPH) by MeOH extract of Rumex species and ascorbic acid as standard. *values are means of triplicate \pm standard error.

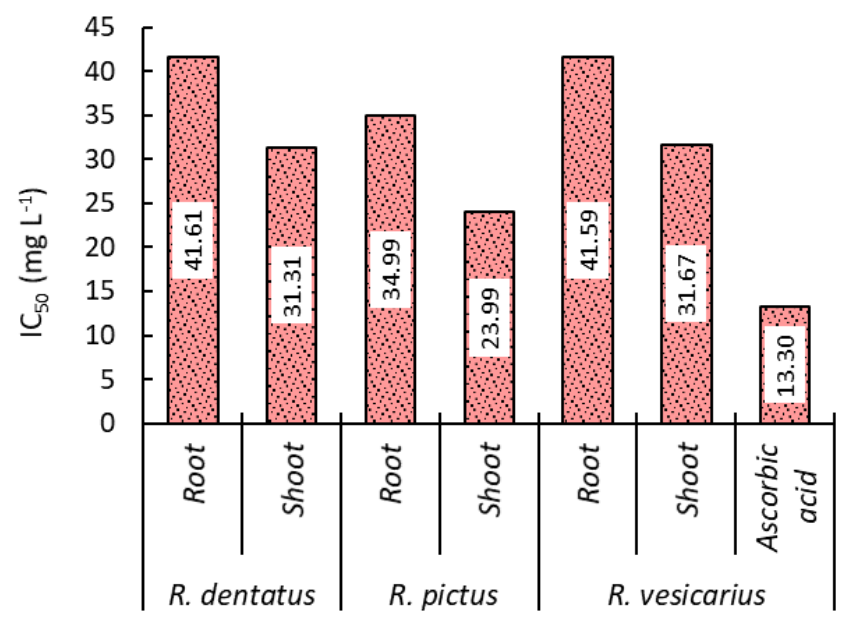

Figure 3. $\mathrm{IC}_{50}$ values of the different studied Rumex spp. and ascorbic acid (standard).

\subsection{Antibacterial activity of $\mathrm{MeOH}$ extract of Rumex species.}

In the agar disc diffusion assay, the antibacterial efficiency of Rumex species was assessed in vitro using ten different pathogenic strains. The root and shoot methanolic extract of the Rumex species had significant anti-microbial inhibitory activity on the growth of the Gram-positive and negative bacteria tested. Generally, Gram-negative bacteria were more sensitive to $\mathrm{MeOH}$ extract than Gram-positive bacteria, except Bacillus subtilis (Table 3). The Escherichia coli and Bacillus subtilis were the most affected bacterial strain, while Pseudomonas aeruginosa and Bacillus cereus were the most resistant to the $\mathrm{MeOH}$ of Rumex species (Tables $2 \& 3$ ). According to their sensitivity, the organisms tested can be sequenced as follows: $E$. coli $<\mathrm{K}$. pneumoniae $<S$. typh $i<P$. aeruginosa for Gram-negative bacteria and $B$. subtilis $<$ S. pneumoniae $<$ L. monocytoyenes $<$ S. epidermis $<S$. aureus $<$ B. cereus for Grampositive bacteria. In addition, it was noted that the antibacterial performance of $R$. dentatus root and $R$. vesicarius shoot $\mathrm{MeOH}$ extract are $100 \%$ broad spectrum against Gram-negative bacteria. Whereas the shoot of $R$. dentatus and $R$. pictus $\mathrm{MeOH}$ extract against Gram-positive 
bacteria is $83.3 \%$ broad spectrum each. Variant activities against the microorganisms test were showed by the antibiotics, ampicillin, cefotaxime and tetracycline. While E. coli was the most sensitive $(30 \mathrm{~mm})$ to cefotaxime, and $L$. monocytoyenes and $S$. aureus was the most susceptible ( 25 and $30 \mathrm{~mm}$, respectively) to ampicillin (Tables $2 \& 3$ ).

From the obtained results, it could be concluded that the activity of the major compounds in the $\mathrm{MeOH}$ of Rumex species could be responsible for the observed potent antimicrobial activity, antioxidant activity, antitumor activity, laxative agents and antimelanogenic activities [16,20,49-51]. Previous findings show that many wild plants against several bacterial and fungal strains were anti-microbial agents [52]. Alkaloids are known to have anti-microbial and anti-inflammatory effects [53,54]. David et al. [55] reported that flavonoids are beneficial for human health. They possess biological and pharmacological activities such as antioxidant and anti-microbial activity [53]. Laouini et al. [56] documented that polyphenols can display antibacterial effects against several pathogenic bacteria and antioxidant, antiallergic, anti-inflammatory, and anticancer agents.

Table 2. The antibacterial activities represented by the inhibition zone diameter ( $\mathrm{mm})$ of the extracted $\mathrm{MeOH}$ from Rumex spp. and standard antibiotics.

\begin{tabular}{|c|c|c|c|c|c|}
\hline \multicolumn{2}{|c|}{$\begin{array}{l}\text { Plant } \mathrm{MeOH} \text { extract } \\
\quad\left(10 \mathrm{mg} \mathrm{L}^{-1}\right)\end{array}$} & \multicolumn{4}{|c|}{ Gram-negative bacteria } \\
\hline Plant species & Plant parts & $\begin{array}{c}\text { Escherichia } \\
\text { coli }\end{array}$ & $\begin{array}{c}\text { Klebsiella } \\
\text { pneumoniae }\end{array}$ & $\begin{array}{c}\text { Pseudomonas } \\
\text { aeruginosa }\end{array}$ & $\begin{array}{c}\text { Salmonella } \\
\text { typhi }\end{array}$ \\
\hline \multirow{2}{*}{ R. dentatus } & Root & 15 & 13 & 10 & 7 \\
\hline & Shoot & 15 & 7 & NA & NA \\
\hline \multirow{2}{*}{ R. pictus } & Root & 10 & 12 & NA & 7 \\
\hline & Shoot & 11 & 6 & NA & 12 \\
\hline \multirow{2}{*}{ R. vesicarius } & Root & 18 & 10 & NA & 8 \\
\hline & Shoot & 11 & 6 & 9 & 12 \\
\hline \multicolumn{6}{|c|}{ Standard antibiotic $\left(10 \mathrm{mg} \mathrm{L}^{-1}\right)$} \\
\hline Ampicillin & & 20 & 5 & NA & NA \\
\hline Cefotaxime & & 30 & 20 & 10 & 10 \\
\hline Tetracycline & & 20 & 20 & NA & 10 \\
\hline
\end{tabular}

Table 3. The anti-microbial activities represented by the inhibition zone diameter (mm) of the extracted $\mathrm{MeOH}$ from Rumex spp. and standard antibiotics.

\begin{tabular}{|c|c|c|c|c|c|c|c|}
\hline \multicolumn{2}{|c|}{$\begin{array}{c}\text { Plant } \mathrm{MeOH} \text { extract } \\
\left(10 \mathrm{mg} \mathrm{L}^{-1}\right)\end{array}$} & \multicolumn{6}{|c|}{ Gram-positive bacteria } \\
\hline Plant species & $\begin{array}{l}\text { Plant } \\
\text { parts }\end{array}$ & $\begin{array}{c}\text { Bacillus } \\
\text { cereus }\end{array}$ & $\begin{array}{c}\text { Bacillus } \\
\text { subtilis }\end{array}$ & $\begin{array}{c}\text { Listeria } \\
\text { monocytoyenes }\end{array}$ & $\begin{array}{c}\text { Staphylococcus } \\
\text { aureus }\end{array}$ & $\begin{array}{c}\text { Staphylococcus } \\
\text { epidermidis }\end{array}$ & $\begin{array}{c}\text { Streptococcus } \\
\text { pneumoniae }\end{array}$ \\
\hline \multirow{2}{*}{ R. dentatus } & Root & 9 & 12 & 6 & NA & NA & 15 \\
\hline & Shoot & NA & 12 & 6 & 6 & 6 & 7.5 \\
\hline \multirow{2}{*}{ R. pictus } & Root & NA & 7 & 6 & NA & NA & 7 \\
\hline & Shoot & NA & 29 & 8 & 10 & 6 & 8 \\
\hline \multirow{2}{*}{ R. vesicarius } & Root & NA & 11 & 6 & NA & NA & 6 \\
\hline & Shoot & NA & 23 & 8 & NA & 6 & 6 \\
\hline \multicolumn{8}{|c|}{ Standard antibiotic $\left(10 \mathrm{mg} \mathrm{L}^{-1}\right)$} \\
\hline Ampicillin & & 5 & 20 & 25 & 30 & 10 & 10 \\
\hline Cefotaxime & & 10 & 5 & 20 & 22 & 20 & 11 \\
\hline Tetracycline & & 10 & 23 & 20 & 20 & 20 & 15 \\
\hline
\end{tabular}

\section{Conclusions}

The phytochemical analysis of Rumex species growing naturally in three heterogeneous habitats in Egypt (cultivated land, coastal and inland desert) disclosed that $\mathrm{MeOH}$ extracts of these species are richer in bioactive compounds such as tannins and phenolics composition. 
There was a comparable difference among Rumex species in a quantity of chemical composition. Whereas no significant variation was observed based on habitat, predominantly coastal and inland desert samples. So the variation is weakly correlated to habitat. Moreover, the $\mathrm{MeOH}$ extract inhibited a set of microbes and showed considerable antioxidant activity. Therefore, the three Rumex species are used in food preservation due to their antioxidant and anti-microbial activities. Further research is, however, recommended for characterizing authentic materials for the assessment of biosafety and efficiency as field scale of the major compounds.

\section{Funding}

This research received no external funding.

\section{Acknowledgments}

This research has no acknowledgment.

\section{Conflicts of Interest}

\section{The authors declare no conflict of interest.}

\section{References}

1. Dang, L.; Van Damme, E.J. Toxic proteins in plants. Phytochemistry 2015, 117, 51-64, https://doi.org/10.1016/j.phytochem.2015.05.020.

2. Fierascu, R.C.; Fierascu, I.; Ortan, A.; Georgiev, M.I.; Sieniawska, E. Innovative approaches for recovery of phyto-constituents from medicinal/aromatic plants and biotechnological production. Molecules 2020, 25, 309, https://doi.org/10.3390/molecules25020309.

3. Algradi, A.M.; Liu, Y.; Yang, B.Y.; Kuang, H.X. Review on the genus Brugmansia: traditional usage, phytochemistry, pharmacology, and toxicity. Journal of Ethnopharmacology 2021, 113910, https://doi.org/10.1016/j.jep.2021.113910.

4. Zahran, M.A.; El-Amier, Y.A. Non-traditional fodders from the halophytic vegetation of the deltaic Mediterranean coastal desert, Egypt. Journal of Biological Science 2013, 13, 226-233, https://doi.org/10.3923/jbs.2013.226.233.

5. Takhtajan, A. Floweringg Plants. Springer, 2009, P 905.

6. Meikle, R.D. Flora of Cyprus. Bentham-Maxon Trust, Royal Botanic Garden, Kew.1985.

7. Zohary, M. Flora Palaestina. The Israel Academy of Sciences, Parts and Humanities, Jerusalem. 1966.

8. Boulos, L. Flora of Egypt. Cairo: Al Hadara Publishing. 1999.

9. Boulos, L. Medicinal plants of North Africa. References Publication. Inc. Algonac, Michigan. 1983.

10. Kadioglu, Z.; Cukadar, K.; Kalkan, N.N.; Vurgun, H.; Kaya, O. December. Wild edible plant species used in the Ağrı province, eastern Turkey. Anales del Jardín Botánico de Madrid, 2020, 77, e098-e098, https://doi.org/10.3989/ajbm.2554.

11. Hadjichambis, A.C.; Paraskeva-Hadjichambi, D.; Della, A.; Elena Giusti, M.; De Pasquale, C.; Lenzarini, C.; Pieroni, A. Wild and semi-domesticated food plant consumption in seven circum-Mediterranean areas. International Journal of Food Sciences and Nutrition, 2008, 59, 383-414, https://doi.org/10.1080/09637480701566495.

12. Fatima, N.; Zia, M.; Rehman, R.; Rizvi, Z.F.; Ahmad, S.; Mirza, B.;Chaudhary, M.F. Biological activities of Rumex dentatus L: Evaluation of methanol and hexane extracts. African Journal of Biotechnology 2009, 8.

13. Al-Rumaih, M.M.; Al-Saad, F.A.; Warsy, A.S. Seasonal variation in mineral content of different organs during development of Rumex vesicarius L. Saudi Journal of Biological Science 2002, 9, 69-79.

14. Mostafa, H.A.M.; Elbakry, A.A.; Eman, A.A. Evaluation of antibacterial and antioxidant activities of different plant parts of Rumex vesicarius L. (Polygonaceae). International Journal of Pharmacy and Pharmaceutical Sciences 2011, 3, 109-118. 
15. Vasas, A.; Orbán-Gyapai, O.; Hohmann, J. The genus Rumex: Review of traditional uses, phytochemistry and pharmacology. Journal of Ethnopharmacology $2015,175, \quad$ 198-228, https://doi.org/10.1016/j.jep.2015.09.001.

16. Süleyman, H.; Demirezer, L. Ö.; Kuruüzüm, A.; Banoğlu, Z. N.; Göçer, F.; Özbakir, G.; Gepdiremen, A. Antiinflammatory effect of the aqueous extract from Rumex patientia L. roots. Journal of Ethnopharmacology 1999, 65, 141-148, https://doi.org/10.1016/S0378-8741(98)00175-5.

17. Getie, M.; Gebre-Mariam, T; Rietz, R.; Höhne, C.; Huschka, C.; Schmidtke, M.; Neubert, R.H.H. Evaluation of the anti-microbial and anti-inflammatory activities of the medicinal plants Dodonaea viscose, Rumex nervosus and Rumex abyssinicus. Fitoterapia 2003, 74, 139-143, https://doi.org/10.1016/S0367326X(02)00315-5.

18. Nisa, H.; Kamili, A.N.; Bandh, S.A.; Lone, B.A.; Parray, J.A. Phytochemical screening, anti-microbial and antioxidant efficacy of different extracts of Rumex dentatus L.a locally used medicinal herb of Kashmir Himalaya. Asian Pacific Journal of Tropical Disease 2013, 3, 434-440, https://doi.org/10.1016/S22221808(13)60097-3.

19. Singh, A.; Rana, S.; Singh, R. Wild and cultivated vegetables of the Indian Himalaya and their use as vegetables and in traditional medicine. International Journal of Vegetable Science 2020, 26, 385-407, https://doi.org/10.1080/19315260.2019.1638480.

20. Litvinenko, Y.A.; MuzychKina, R. Phytochemical investigation of biologically active substances in certain Kazakhstan Rumex species. 1. Journal Chemistry of Natural Compounds 2003, 39, 446449, https://doi.org/10.1023/B:CONC.0000011117.01356.4c.

21. El-Bakry, A.A.; Mostafa, H.A.M.; Alam, E.A. Antioxidant activity of Rumex vesicarius L. at the vegetative stage of growth. Asian Journal of Pharmaceutical and Clinical Research 2012, 5, 111-117.

22. Alelign, T.; Chalchisa, D.; Fekadu, N.; Solomon, D.; Sisay, T.; Debella, A.; Petros, B. Evaluation of acute and sub-acute toxicity of selected traditional antiurolithiatic medicinal plant extracts in Wistar albino rats. Toxicology Reports 2020, 7, 1356-1365, https://doi.org/10.1016/j.toxrep.2020.10.001.

23. Tukappa, A.N.K.; Londonkar, R.L.; Nayaka, H.B.; Kumar S.C.B. Cytotoxicity and hepatoprotective attributes of methanolic extract of Rumex vesicarius L. Biological Research 2015, 48, 1-9, https://doi.org/10.1186/s40659-015-0009-8.

24. El-Amier, Y.A.; El Hayyany, L.Y. Floristic composition and species diversity of plant communities associated with genus Atriplex in Nile Delta coast, Egypt. Asian Journal of Conservation Biology 2020, 9 , $11-24$.

25. Zaki, A.A.; Ross, S.A.; El-Amier, Y.A.; Khan, I.A. New flavans and stilbenes from Cyperus conglomeratus. Phytochemistry Letters, 2018, 26, 159-163, https://doi.org/10.1016/j.phytol.2018.05.032.

26. Harborne, J.B. Phenolic compounds, In Phytochemical methods, Springer, Dordrecht, 1973, 33-88, https://doi.org/10.1007/978-94-009-5921-7_2.

27. Trease, G.E.; Evans W.C. Pharmacognosy (13th edn). Bailliere Tindall, London, 1989, 176-180.

28. Sofowora, A. Screening plants for bioactive agents, medicinal plants and traditional medicinal in Africa. Second Ed. Spectrum Books Ltd, Sunshine House, Ibadan, Nigeria, 1993, 134-156.

29. Obadoni, B.O.; Ochuko P.O. Phytochemical studies and comparative efficacy of the crude extracts of some haemostatic plants in Edo and Delta States of Nigeria. Global Journal of Pure and Applied Sciences 2002, 8, 203-208, https://doi.org/10.4314/gjpas.v8i2.16033.

30. Stankovic, M.S. Total phenolic content, flavonoid concentration and antioxidant activity of Marrubium peregrinum L. extracts. Kragujevac Journal of Science 2011, 33, 63-72.

31. Chlopicka, J.; Pasko, P.; Gorinstein, S.; Jedryas, A.; Zagrodzki, P. Total phenolic and total flavonoid content, antioxidant activity and sensory evaluation of pseudocereal breads. LWT-Food Science and Technology 2012, 46, 548-555, https://doi.org/10.1016/j.lwt.2011.11.009.

32. Jasuja, N.D.; Sharma, S.K.; Saxena, R.; Choudhary, J.; Sharma, R.; Joshi, S.C. Antibacterial, antioxidant and phytochemical investigation of Thuja orientalis leaves. Journal of Medicinal Plants Research 2013, 7 , 1886-1893, https://doi.org/10.5897/JMPR12.1323.

33. Miguel, M.G.; Cruz, C.; Faleiro, L.; Simões, M.T.; Figueiredo, A.C.; Barroso, J.G.; Pedro, L.G. Foeniculum vulgare essential oils: chemical composition, antioxidant and antimicrobial activities. Natural product communications 2010, 5, https://doi.org/10.1177\%2F1934578X1000500231.

34. Cappuccino J.G.; Sherman N. Microbiology: A laboratory Manual. Peason Benjamin Cummings. San Francisco, US, 2008. 
35. Ncube, B.; Finnie, J.F.; Van Staden, J. Quality from the field: the impact of environmental factors as quality determinants in medicinal plants. South African Journal of Botany 2012,82, 11-20, https://doi.org/10.1016/j.sajb.2012.05.009.

36. Rogowska, A.; Szakiel, A. The role of sterols in plant response to abiotic stress. Phytochemistry Reviews 2020, 19, 1525-1538, https://doi.org/10.1007/s11101-020-09708-2.

37. Reginato, M.; Varela, C.; Cenzano, A.M.; Luna, V. Role of polyphenols as antioxidants in native species from Argentina under drought and salinization. In Reactive oxygen species and oxidative damage in plants under stress. Springer, Cham. 2015, 247-267, https://doi.org/10.1007/978-3-319-20421-5_10.

38. Beddou, F.; Bekhechi, C.; Ksouri, R.; Sari, D.C.; Bekkara, F.A. Potential assessment of Rumex vesicarius L. as a source of natural antioxidants and bioactive compounds. Journal of Food Science and Technology 2015, 52, 3549-3560, https://doi.org/10.1007/s13197-014-1420-9.

39. Shakir, U.; Gul, J.; Farzana, G.; Siraj, K.; Husna, H.; Jan, S.; Abidullah, S. Phytochemistry and antibacterial activities of some selected plants of war affected area of bajaur agency, Pakistan. Journal of Pharmacognosy and Phytochemistry 2018, 7, 415-422.

40. Ammar, N.M.; Ayoub, N.A.; El-Ahmady, S.H.; Abou El-Kassem, L.T.; Abou Zeid, E.M. Phytochemical and cytotoxic studies of Rumex pictus Forssk. and Rumex vesicarius L. (Family Polygonaceae) growing in Egypt. European Journal of Medicinal Plants 2015, 1-13, https://doi.org/10.9734/EJMP/2015/19830.

41. Zhou, Y.; Jiang, Z.; Lu, H.; Xu, Z.; Tong, R.; Shi, J.; Jia, G. Recent advances of natural polyphenols activators for Keap1-Nrf2 signaling pathway. Chemistry \& Biodiversity 2019, 16, e1900400, https://doi.org/10.1002/cbdv.201900400.

42. Alzuaibr, F.M.; El-Amier, Y.A.; Al-Barati, S.A. Phytochemical screening, antioxidant, and allelopathic activities of Diplotaxis harra crude extracts. Plant Archives 2020, 20, 621-626.

43. El-Amier, Y.A.; Abo-Aisha, I.A. Phytochemical constituents of common growing Fagonia species (Zygophyllaceae) in Egyptian deserts and its biological activities. Plant Archives 2019, 19, 2213-2219.

44. Muniyandi, K.; George, E.; Sathyanarayanan, S.; George, B.P.; Abrahamse, H.; Thamburaj, S.; Thangaraj, P. Phenolics, tannins, flavonoids and anthocyanins contents influenced antioxidant and anticancer activities of Rubus fruits from Western Ghats, India. Food Science and Human Wellness 2019, 8, 73-81. https://doi.org/10.1016/j.fshw.2019.03.005.

45. El-Amier, Y.A.; Al-hadithy, O.N. Phytochemical constituents, antioxidant and allelopathic activities of Aizoon canariense L. On Zea mays (L.) and associated weeds. Plant Archives 2020, 20, 303-310.

46. Ma, Y.; Dias, M.C.; Freitas, H. Drought and salinity stress responses and microbe-induced tolerance in plants. Frontiers in Plant Science 2020, 11, 1750, https://doi.org/10.3389/fpls.2020.591911.

47. Zlatev, Z.S.; Lidon, F.J.; Kaimakanova, M. Plant physiological responses to UV-B radiation. Emirates Journal of Food and Agriculture 2012, 481-501, https://doi.org/10.9755/ejfa.v24i6.14669.

48. Nagahama, N.; Gastaldi, B.; Clifford, M.; Manifesto, M.M; Fortunato, R.H. The influence of environmental variations on the phenolic compound profiles and antioxidant activity of two medicinal Patagonian valerians (Valeriana carnosa Sm. and V. clarionifolia Phil.). AIMS Agricuiture and Food 2021, 6, 106-124, https://hdl.handle.net/20.500.12123/8469.

49. Demirezer, L.O. Comparison of two Rumex species with a spectrophotometric method and chromatographic identification with regard to anthraquinone derivatives. Planta Medica 1993, 630-635, https://doi.org/10.1055/s-2006-959865.

50. Yildirim, A.; Mavi, A.; Kara, A.A. Determination of antioxidant and anti-microbial activities of Rumex crispus L. extracts. Journal of Agriculture Food and Chemistry 2001, 49, 4083-4089, https://doi.org/10.1021/jf0103572.

51. Humeera, N.; Kamili, A.N.; Bandh, S.A.; Lone, B.A.; Gousia, N. Antimicrobial and antioxidant activities of alcoholic extracts of Rumex dentatus L. Microbial Pathogensis 2013, 57, 17-20, https://doi.org/10.1016/j.micpath.2013.02.001.

52. Niu, B.; Wang, W.; Yuan, Z.; Sederoff, R.R.; Sederoff, H.; Chiang, V.L.; Borriss, R. Microbial interactions within multiple-strain biological control agents impact soil-borne plant disease. Frontiers in Microbiology 2020, 11, 2452, https://doi.org/10.3389/fmicb.2020.585404.

53. El-Amier, Y.A.; Al-hadithy, O.N.; Fahmy, A.A.; El-Zayat, M.M. Phytochemical analysis and biological activities of three wild Mesembryanthemum species growing in heterogeneous habitats. Journal of Phytology 2021, 13, 1-8, https://doi.org/10.25081/jp.2021.v13.6403. 
54. Patel, K.; Gadewar, M.; Tripathi, R.; Prasad, S.K.; Patel, D.K. A review on medicinal importance, pharmacological activity and bioanalytical aspects of beta-carboline alkaloid "Harmine". Asian Pacific Journal of Tropical Biomedicine 2012, 2, 660-664, https://doi.org/10.1016/S2221-1691(12)60116-6.

55. Devi, S.; Kumar, V.; Singh, S.K.; Dubey, A.K.; Kim, J.J. Flavonoids: Potential candidates for the treatment of neurodegenerative disorders. Biomedicines 2021, 9, 99, https://doi.org/10.3390/biomedicines9020099.

56. Bakhouche, I.; Aliat, T.; Boubellouta, T.; Gali, L.; Şen, A.; Bellik, Y. Phenolic contents and in vitro antioxidant, anti-tyrosinase, and anti-inflammatory effects of leaves and roots extracts of the halophyte Limonium delicatulum. South African Journal of Botany 2021, 139, 42-49, https://doi.org/10.1016/j.sajb.2021.01.030. 